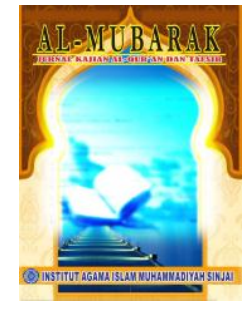

\title{
TAUHID DALAM PERSPEKTIF FARID ESACK
}

\author{
Basri $^{1}$ \\ ${ }^{1}$ IAIN Sultan Amai Gorontalo \\ JI. Gelatik, Heledulaa, Kota Timur, Kota Gorontalo, Gorontalo 96135 \\ E-mail:basrialmarosy@yahoo.com, Tlp:+6282121586218
}

\begin{abstract}
Abstrak
Tulisan ini mengulas pandangan Farid Esack mengenai makna Tauhid dalam al-Qur'an. Dengan adanya problem kemanusiaan yang dihadapi oleh rakyat Afrika Selatan seperti rasialisme, patriarkhi, dan kapitalisme, Farid Esack kemudian merefleksikan kondisikondisi obyektif masyarakat Afrika Selatan tersebut baru kemudian melihat hamparan teks Al-Qur'an hingga ditemukan makna-maknanya yang baru dari teks tersebut, di antaranya ayat-ayat yang berkaitan dengan tauhid. Tulisan ini akan memaparkan terlebih dahulu konteks kehidupan Farid Esack, kemudian menjelaskan penafsiran Farid Esack mengenai ayat-ayat tauhid, dan terakhir menguraikan signifikansi interpretasi Farid Esack sebagai landasan dalam melakukan aksi pembebasan.
\end{abstract}

Kata Kunci: Farid Esack, Tauhid, Afrika Selatan, Teologi Pembebasan

\section{Pendahuluan}

Islam adalah agama dengan misi universalnya mengajak semua manusia menyembah Allah Yang Maha Esa sekaligus menjadi rahmat bagi seluruh alam. Dalam al-Qur'an secara jelas disebutkan bahwa Allah swt. mengutus Nabi Muhammad saw. untuk menjadi rahmat bagi seluruh alam sekaligus mengirimkan wahyu-Nya kepada beliau untuk menyebarkan risalah tauhid bahwa Allah swt. adalah Tuhan Yang Maha Esa:

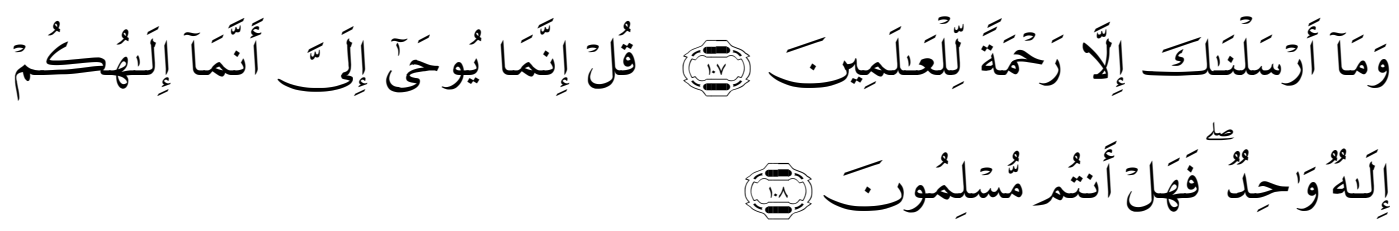

Terjermahnya:

"Dan Kami tidak mengutus engkau (Muhammad) melainkan untuk (menjadi) rahmat bagi seluruh alam. Katakanlah (Muhammad), "Sungguh apa yang diwahyukan kepadaku ialah bahwa Tuhanmu adalah Tuhan Yang Esa, maka apakah kamu telah berserah diri (kepada-Nya)?” (QS. Al-Anbiya: 107-108)

Ayat ini menerangkan bahwa Rasulullah saw. itu adalah rahmat. Bukan hanya karena beliau membawa ajaran Islam yang penuh dengan kasih sayang dan 


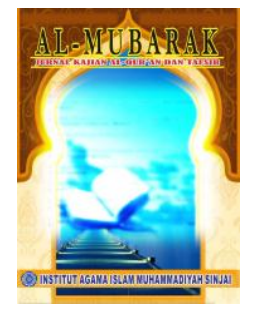

\section{Al-MUBARAK}

Jurnal Kajian Al-Quran \& Tafsir

Volume 5, No. 1, 2020

P-ISSN: 2548-7248

E-ISSN: 2715-5692

Homepage : http://journal.iaimsinjai.ac.id/indeks.php/al-mubarak

kelembutan, namun juga karena sosok dan kepribađian beliau adalah rahmat yang dianugerahkan Allah kepadanya yang tercermin dari sikap, ucapan, perbuatan, dan seluruh totalitas kehidupannya. Sosok kerahmatan Rasulullah ini bertujuan untuk mempersamakan totalitas beliau dengan ajaran yang disampaikan, karena ajaran beliau pun adalah rahmat yang menyeluruh. Dengan demikian menyatulah ajaran dan penyampai ajaran dan menyatu risalah dan rasul-Nya (Quraish Shihab, 2002: 133-134).

Setelah ayat 107 yang mengemukakan keistimewaan Nabi Muhammad saw. dan ajaran Islam yang dibawanya, maka pada ayat 108 beliau diperintahkan untuk menyebarkan tauhid; "Bahwa Tuhan kamu adalah Tuhan Yang Esa maka apakah kamu (termasuk golongan) orang-orang muslim". Tauhid yang diajarkan oleh Nabi Muhammad saw. ini adalah sama dengan ajaran yang disampaikan oleh para Nabi sebelumnya, dan ini adalah prinsip dasar agama Islam. Ibarat kata, kalau dalam alam raya ini ada matahari yang menjadi sumber kehidupan makhluk di muka bumi dan planet-planet di tata surya turut serta mengelilinginya, maka akidah tauhid merupakan matahari kehidupan ruhani dan berkeliling pula di sekitarnya sekian kesatuan yang tidak boleh melepaskan diri dari tauhid itu. Karena jika ia lepas, maka akan binasa sebagaimana planet-planet yang mengitari matahari itu jika keluar dari orbitnya. Kesatuan yang dimaksud ialah kesatuan alam semesta, kesatuan kehidupan dunia dan akhirat, kesatuan natural dan supranatural, kesatuan ilmu pengetahuan, kesatuan sumber ajaran syari'at, kesatuan kemanusiaan, keatuan umat, kesatuan kepribadian manusia, kesatuan jasmani dan ruhani, dan lain sebagainya (Quraish Shihab, 2002: 136-137).

Jadi dari ayat terebut di atas, dapat dipahami bahwa Islam sebagai agama rahmat bagi seluruh alam, yang memberikan kebaikan nyata bagi kehidupan khususnya manusia, inti ajaran dan pijakannya dimulai dari tauhid. Namun pemaknaan tauhid itu sendiri sering dibatasi hanya pada persoalan meng-Esa-kan Allah semata. Sekalipun bisa dikatakan bahwa pembatasan makna tauhid pada soal ketuhanan di masa dahulu tidak menjadi masalah dalam mewujudkan Islam rahmatan lil 'alamin karena umat generasi awal hidup dekat dengan masa Nabi, menghayati dengan baik spirit dan karakteristik agama Islam sebagai agama 


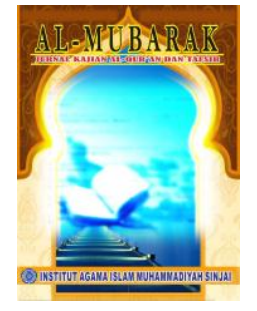

AI-MUBARAK

Jurnal Kajian Al-Quran \& Tafsir

Volume 5, No. 1, 2020

P-ISSN: 2548-7248

E-ISSN: 2715-5692

Homepage : http://journal.iaimsinjai.ac.id/indeks.php/al-mubarak

universal, agama rasional, agama peduli, dan agama peradaban. Namun seiring dengan perkembangan zaman serta masa kenabian sudah teramat jauh, maka pembatasan itu menjadi masalah dalam mewujudkan Islam yang ideal karena telah kehilangan spirit dan penghayatan karakteristiknya. Pembatasan itu sejak beberapa abad yang lalu telah menjadikan Islam sebagai priestly religion yang hanya menekankan aspek ritual saja, tidak lagi menjadi prophetic religion yang peduli terhadap penderitaan manusia, menjadi problem solver terhadap masalah yang dihadapi, serta menjadi pembangun peradaban (M. Su'ud dan Syukron Affani, 2009: 22).

Hadirnya Farid Esack yang merupakan salah satu tokoh tafsir kontemporer di Afrika Selatan, di mana beliau telah mengembangkan seperangkat tafsir alQur'an yang bernuansa sosial dalam menghadapi problem kemanusiaan yang dihadapi; berupa penindasan, ketidakadilan, dan kesewenang-wenangan, dengan menjadikan prinsip tauhid sebagai salah satu spirit dalam melakukan pembebasan, merupakan salah satu upaya untuk mewujudkan bahwa ajaran Islam itu adalah rahmatan lil 'alamin.

\section{Metode}

Metode penelitian adalah bagian penting dalam sebuah proses penelitian. Metode yang tidak tepat akan menghasilkan sebuah kajian yang keliru, begitupun sebaliknya, jika metodenya benar, maka hasilnya pun akan benar. Oleh karena metodologi sebagai sebuah proses kerja intelektual, maka keilmiahan dan pembahasan yang sistematis menjadi suatu keharusan. Dengan demikian, terlebih dahulu akan dipaparkan metodologi penelitian yang digunakan dalam artikel ini yang meliputi: jenis penelitian, pendekatan dan metode yang digunakan, serta teknik pengumpulan dan sumber data.

\subsection{Jenis Penelitian}

Adapun penelitian ini jika dilihat dari sifatnya, dapat dikategorikan penelitian budaya, karena artikel ini adalah kajian mengenai ide, konsep, atau gagasan seorang tokoh. Sedangkan jika dilihat dari tujuannya, penelitian ini termasuk penelitian deskriptif-eksplanatif, yakni mendeskripsikan terlebih dahulu mengenai konteks sosiohistoris kehidupan tokoh yang dikaji, kemudian 


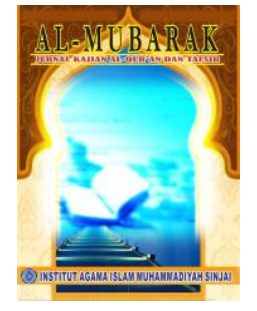

AI-MUBARAK

Jurnal Kajian Al-Quran \& Tafsir

Volume 5, No. 1, 2020

P-ISSN: 2548-7248

E-ISSN: 2715-5692

Homepage : http://journal.iaimsinjai.ac.id/indeks.php/al-mubarak

menguraikan penafsiran beliau tentang tauhid, serta menjelaskan signifikansi penafsiran tersebut yang digunakan sebagai landasan dalam melakukan aksi pembebasan.

\subsection{Pendekatan dan Metode yang Digunakan}

Pendekatan yang digunakan dalam kajian ini ialah pendekatan historisfilosofis dan pendekatan filosofis. Penggunaan pendekatan ini dimaksudkan untuk menganalisis tiga unsur kajian, yakni: (a) menganalisis teks itu sendiri; (b) merunut akar-akar historis secara kritis latar belakang tokoh tersebut mengapa ia mengusung gagasan penafsirannya; dan (c) menganalisa kondisi sosio-historis yang melingkupi tokoh tersebut. Dan dengan pendekatan filosofis, maka akan nampak sigifikansi dari penafsiran tokoh yang dikaji sesuai dengan latar sosiohistorisnya.

Sedangkan metode yang digunakan dalam kajian ini ialah metode induktif. Metode ini diterapkan jika ingin melakukan suatu proses penyimpulan setelah melakukan pengumpulan data dan menganalisanya. Proses induktif ini diterapkan berdasarkan data-data yang telah dikumpulkan dan dilakukan analisis, yaitu melalui suatu sintesis dan penyimpulan secara induktif aposteriori.

\subsection{Pengumpulan dan Sumber Data}

Penelitian ini merupakan penelitian kepustakaan (Library Research), yaitu penelitian yang data-datanya diperoleh melalui studi pustaka, dengan merujuk kepada sumber utama, yakni karya Farid Esack. Adapun data-data yang hendak diteliti terdiri dari data primer dan data sekunder. Data primer ialah data-data yang bersumber dari karya Farid Esack itu sendiri, yakni Qur'an, Liberation and Pluralism An Islamic Perspective of Interreligious Solidarity Against Oppression (1997), serta tulisan lainnya yang berjudul "Spektrum Teologi Progresif di Afrika Selatan” dalam buku Dekonstruksi Syari ‘h (II): Kritik Konsep, Penjelajahan Lain.

Sedangkan data sekunder ialah buku-buku, kitab, artikel, dan sumber data lainnya yang berkaitan dengan pemikiran tokoh tersebut. Dan juga beberapa buku lain yang terkait dengan objek kajian ini yang sekiranya dapat digunakan untuk membantu menganalisis penafsiran Farid Esack. 


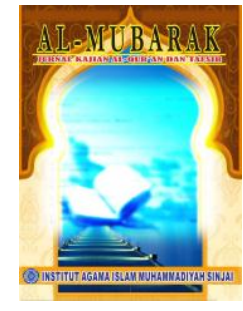

\section{Al-MUBARAK}

Jurnal Kajian Al-Quran \& Tafsir

Volume 5, No. 1, 2020

P-ISSN: 2548-7248

E-ISSN: 2715-5692

Homepage : http://journal.iaimsinjai.ac.id/indeks.php/al-mubarak

Dengan adanya data-data tersebut, maka langkah-langkah penelitian ini adalah sebagai berikut:

a. Penulis akan menginventarisasi data dan menyeleksinya, khususnya karyakarya Farid Esack, serta buku-buku lainnya yang terkait dengan penafsiran beliau.

b. Penulis dengan cermat akan mengkaji data tersebut secara komprehensif dan kemudian mengabstraksikan dan mendeskriptifkan bagaimana konsep tauhid dalam perpektif Farid Esack serta sigifikansinya.

c. Penulis akan membuat kesimpulan-kesimpulan secara cermat sebagai output dari penelitian ini.

\section{Pembahasan}

\subsection{Farid Esack dan Konteks Afrika Selatan}

Sebuah produk pemikiran tentunya merupakan anak zamannya. Artinya, setiap gagasan atau ide dari seorang penulis selalu terkait erat dengan setting sosio-historisnya. Tak terkecuali Farid Esack yang merupakan salah seorang tokoh intelektual Muslim kontemporer yang tak asing lagi di dunia akademik, khususnya di Indonesia. Beberapa karya-karyanya sudah tersebar luas bahkan telah diterjemahkan ke dalam bahasa Indonesia. Bangunan pemikiran Farid Esack sangat dipengaruhi oleh kondisi sosio-historis Afrika Selatan yang sarat dengan penindasan dan kemiskinan, sehingga ia kemudian lebih dikenal sebagai seorang sarjana Muslim progresif dari Afrika Selatan, penulis, dan juga aktivis politik.

Potret kehidupan di Afrika Selatan tempat Farid Esack lahir dan dibesarkan banyak diceritakan oleh Farid Esack sendiri dalam bukunya Qur`an, Liberatiaon and Pluralism: An Islamic Perspective of Interreligious Solidarity against Oppression. Secara garis besar, ada tiga problem kemanusiaan yang dihadapi rakyat Afrika Selatan tempat Farid Esack hidup; yakni problem rasialisme, patriarkhi dan kapitalisme yang dilakukan oleh kelompok kulit putih atas kelompok selain kulit putih (Farid Esack, 1996: 193). Pertama, rasialisme di Afrika Selatan ditunjukkan dengan adanya sistem kekuasaan Apartheid yang berlaku. Apartheid adalah politik diskriminasi warna kulit yang diterapkan dahulu di Republik Afrika Selatan antara keturunan dari Eropa (kulit putih) terhadap 


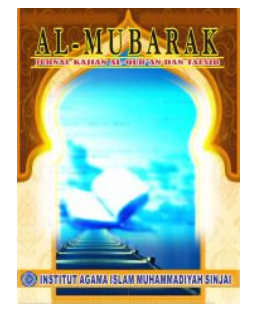

AI-MUBARAK

Jurnal Kajian Al-Quran \& Tafsir

Volume 5, No. 1, 2020

P-ISSN: 2548-7248

E-ISSN: 2715-5692

Homepage : http://journal.iaimsinjai.ac.id/indeks.php/al-mubarak

penduduk kulit berwarna. Kebijakan ini dimulai sejak adanya kolonialisme Eropa pada pertengahan abad ke-17. Partai Nasional yang berkuasa saat itu sejak 1948 hingga tahun 1993 kemudian menjadikannya sebagai ideologi resmi dan merupakan pedoman untuk bersikap terhadap bangsa kulit hitam yang berjumlah 80\% dari keseluruhan penduduk (Heppy El Rais, 2012, 47). Dengan diterapkannya sistem apartheid saat itu, mayoritas kelompok kulit hitam hampir sama sekali tidak diikutsertakan dalam pengambilan keputusan-keputusan politik dan tidak diberi hak-hak ekonomi dan sosial sebagaimana yang dinikmati oleh penduduk kulit putih. Peristiwa ini terus menghantui penduduk Afrika Selatan pada umumnya di mana orang kulit putih memiliki prioritas untuk mendapatkan perumahan, pekerjaan, pendidikan, dan akses kekuasaan politik (Kirdi Dipoyudo, 1977: 15).

Kedua, budaya patriarkhi di Afrika Selatan yang menempatkan perempuan pada posisi subordinat. Kasus pemerkosaan yang dialami oleh ibunya sendiri merupakan peristiwa pahit dan menyakitkan bagi Farid Esack. Secara umum, kelompok keagamaan tertentu telah memperlakukan perempuan secara tidak adil dan semena-mena. Atas nama Agama, mereka menempatkan perempuan pada wilayah domestik dan selalu dipersalahkan bila berhubungan dengan laki-laki (Farid Esack, 1997: 4).

Ketiga, adalah masalah kapitalisme kelompok kulit putih. Seperti yang telah dijelaskan sebelumnya, bahwa salah satu kebijakan apartheid ialah tempat tinggal dipisahkan berdasarkan stratifikasi ras yang ada. Orang-orang kulit hitam banyak yang tinggal di daerah perbatasan utara hingga perbatasan timur Afrika Selatan. Bagi orang-orang kulit hitam yang berada di luar daerahnya lebih dari 72 jam tanpa izin khusus dari Native Labour Officer, maka mereka akan dipenjara. Di daerah kulit hitam, pembagian daerah kemudian dilakukan berdasarkan kelompok etnis yang ada. Daerah-daerah tersebut kemudian disebut dengan Homelands (tanah air) atau Bantustans (daerah orang Bantu). Karena bersifat otonomi daerah, perkembangan ekonomi di Homelands tidaklah baik. Sumber daya di daerah tersebut juga tidak banyak sehingga tidak bisa memenuhi kebutuhan masyarakat. Belum lagi pertambahan penduduk yang kian banyak setiap tahunnya, membuat 


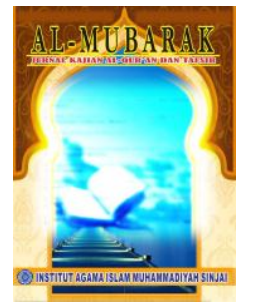

AI-MUBARAK

Jurnal Kajian Al-Quran \& Tafsir

Volume 5, No. 1, 2020

P-ISSN: 2548-7248

E-ISSN: 2715-5692

Homepage : http://journal.iaimsinjai.ac.id/indeks.php/al-mubarak

Homelands menjadi padat dan kumuh. Berbeda dengan kondisi di daerah milik orang kulit putih. Daerah mereka luas dengan penduduk sedikit. Belum lagi sumber daya alam yang melimpah, seperti berlian, mangan, dan emas. Kulit putih saat itu sangatlah makmur. Tidak hanya masalah tempat tinggal yang dibedakan, masalah pekerjaan, pendidikan, dan penikahan juga di diskriminasi. Orang kulit hitam umumnya hanya menjadi buruh, namun karena mereka bertambah banyak setiap tahunnya, mereka lambat laun banyak yang menganggur (Agus Budiman, 2013: 19-20).

Di tempat dengan kondisi seperti inilah Faid Esack lahir dan dibesarkan. Ia lahir pada tanggal 8 Maret 1959 di Wynberg, Capetown, Afrika Selatan. Masa kecilnya berada dalam asuhan ibu dengan lima saudara laki-lakinya. Tiga diantaranya berasal dari perkawinan sebelumnya. Ayahnya meninggalkan keluarganya ketika Farid Esack berusia tiga minggu. Esack kecil tumbuh dalam kondisi keluarga yang serba kekurangan. Ibunya hanyalah seorang karyawan pabrik dengan gaji rendah, beliau meninggal pada usia 52 tahun. Untuk mencukupi kebutuhan makan saja terkadang harus meminta pada tetangga, atau mengais sisa makanan. Bersekolah pun sudah terbiasa tanpa memakai sepatu. Bahkan ketika musim salju, ia harus berlari agar kakinya tidak membeku (Farid Esack, 1997: 2).

Pemberlakuan politik Apartheid di Afrika Selatan pun memaksa keluarga Esack untuk tinggal di Bontehouwel, sebuah wilayah khusus untuk penduduk kulit berwarna di Cape Flats, Afrika Selatan. Wilayah tersebut merupakan tanah paling tandus dan kemudian dihuni oleh orang kulit hitam, keturunan India, dan kulit berwarna atas ketetapan dalam Group Areas Act (Akta Wilayah Kelompok). Struktur masyarakat Afrika Selatan kala itu juga sangat beragam, baik agama maupun ras. Esack menyebut dari dulu Afrika Selatan adalah masyarakat multiagama yang hidup saling berdampingan. Keberagaman semakin nampak ketika para pendatang berdatangan. Di antaranya ialah Kristen Belanda, budak Muslim, pelarian politik dari Indonesia, serta kedatangan Yahudi dari Eropa Timur (Farid Esack, 1997: 2-3). 


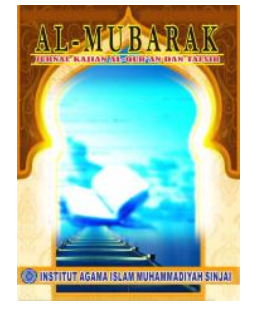

AI-MUBARAK

Jurnal Kajian Al-Quran \& Tafsir

Volume 5, No. 1, 2020

P-ISSN: 2548-7248

E-ISSN: 2715-5692

Homepage : http://journal.iaimsinjai.ac.id/indeks.php/al-mubarak

Seperti inilah fase kehidupan Farid Esack dahulu, penderitaan hidup yang dialamnya serta keluarganya adalah gambaran mikro dari derita rakyat Afrika Selatan pada umumnya akibat perlakuan diskriminatif rezim apartheid. Sebuah kenyataan pahit yang dialami keluarganya itu menjadi salah satu inspirasi penting dalam perkembangan pemikiran Esack yang meyakini bahwa berteologi bukan hanya berarti mengurusi "urusan" Tuhan semata: neraka, surga dan lain-lain. Baginya, teologi yang terlalu mengurusi Tuhan, sementara Tuhan adalah zat yang tidak perlu diurus, adalah teologi mubadzir yang terlalu banyak menyedot energi umat. Esack meyakini bahwa teologi harus dipraksiskan, bukannya digenggam erat-erat untuk tujuan kesalehan personal (individual piety). Dengan mendekati dan mengasihi makhluk-Nya, serta memperjuangkan bebasan, maka kita sama saja telah mengabdi kepada Tuhan (Farid Esack, 1997: 7-13).

\subsection{Tauhid dalam Perspektif Farid Esack}

Dari segi etimologi, kata "Tauhid” (توحيد) berasal dari akar kata "وحد", yang terdiri dari susunan huruf "waw”, “ha”, dan “dal”, yang berarti sendiri (الالْفِفرَادِ), satu (وَاحِ), atau tunggal (الَْحَحَدِ) (Ahmad bin Faris bin Zakariya, 1979: 90). Sebagai istilah teknis dalam Ilmu Kalam, kata ini dimaksudkan sebagai paham "me-Maha Esa-kan Tuhan" atau dengan kata lain ajaran "Ketuhanan Yang Maha Esa" alias "monoteisme" (Nurcholish Madjid, 2005: 71). Menurut Farid Esack, walaupun bentuk kata "tauhid" tidak terdapat dalam al-Qur'an, namun pemaknaan tauhid sebagai "iman kepada Tuhan Yang Esa tanpa sekutu, Wujud Kesatuan, yang Kesatuannya bersifat kekal dan tanpa bandingan”, dipahami dari QS. Al-Ikhlas: 14 (Farid Esack, 1997: 90).

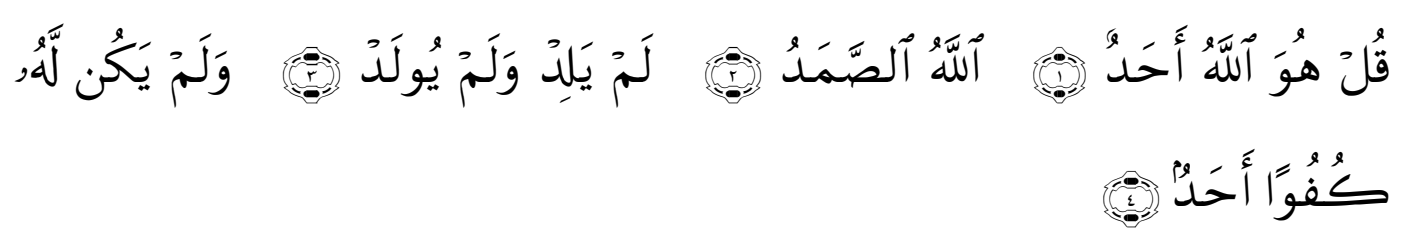

Terjemahnya:

"Katakanlah: "Dia-lah Allah, Yang Maha Esa. Allah adalah Tuhan yang bergantung kepada-Nya segala sesuatu. Dia tiada beranak dan tidak pula diperanakkan, dan tidak ada seorangpun yang setara dengan Dia."

Pada ayat ini, Keesaan Allah swt. disebut dengan menggunakan kata "حد".

Dari segi bahasa, kata ini walaupun sinonim dengan kata "وحد", masing-masing 


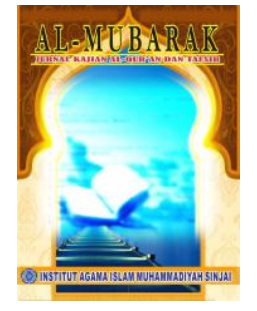

AI-MUBARAK

Jurnal Kajian Al-Quran \& Tafsir

Volume 5, No. 1, 2020

P-ISSN: 2548-7248

E-ISSN: 2715-5692

Homepage : http://journal.iaimsinjai.ac.id/indeks.php/al-mubarak

memiliki makna dan penggunaan tersendiri. Kata "디" hanya digunakan untuk sesuatu yang tidak dapat menerima penambahan (dua, tiga, dan seterusnya). Sedangkan kata "وحد" dapat menerima penambahan sehingga menjadi dua, tiga, dan seterusnya. Sekalipun pada QS. Al-Baqarah: 163 Allah swt. juga disifati dengan kata "واحد", namun ini menunjuk kepada keesaan zat-Nya disertai dengan keragaman sifat-sifat-Nya. Yang berarti di samping Allah swt. itu Maha Esa, Dia juga Maha Pengasih, Maha Penyayang, Maha Tahu, dan sebagainya. Sedangkan kata " pada QS. Al-Ikhlas tadi hanya mengacu kepada keesaan zat-Nya saja, tanpa memperhatikan keragaman sifat-sifat-Nya (Quraish Shihab, 2002: 717).

Farid Esack menjelaskan bahwa tauhid merupakan inti, pusat, dan akhir dari seluruh tradisi Islam. Oleh karenanya, sifak keholistikan Islam berpijak dari prinsip tauhid ini, termasuk dalam hal sosiopolitik. Menurut beliau, keyakinan bahwa tauhid adalah jantung bagi pandangan sosiopolitik yang komprehensif, meski tak sepenuhnya baru, telah berkembang pesat dalam dekade tarakhir, khususnya dalam beberapa aliran ideologis di Iran yang mencetuskan revolusi 1979. Dua sosok paling keras yang mendukung tauhid sebagai suatu pandangan dunia demi mewujudkan keesaan Tuhan dalam sistem sosiopolitik dan hubunganhubungan manusia adalah Ali Syari`ati dan Mujahidin Khalq di Iran. Pendapat Ali Syari`ati yang dikutip oleh Farid Esack menunjukkan apresiasi revolusionernya tentang tauhid dengan mengatakan bahwa dalam Islam, tauhid adalah worldview yang hidup dan penuh makna, menentang keserakahan dan bertujuan memberantas penyakit yang muncul dari penumpukan uang dan penyembahan harta. Ia menghapus stigma eksploitasi dan aristokrasi. Ketika jiwa tauhid bangkit kembali dan peran historisnya disadari oleh seseorang, maka jiwa akan bangkit demi kesadaran, keadilan, kemerdekaan manusia, pembangunan, dan pertumbuhan (Farid Esack, 1997: 90-91).

Memang seiring dengan berjalannya waktu, setidaknya ada tiga hal yang sering merusak tatanan kesatuan bangsa atau dikenal dengan sebutan tauhid sosial atau tauhid al-ummah ini, yang juga sering menyebabkan sekelompok masyarakat memperbudak kelompok lain. Ketiga hal itu ialah keturunan, kekuasaan, dan kekayaan. Kebanggaan karena keturunan telah menimbulkan feodalisme dan 


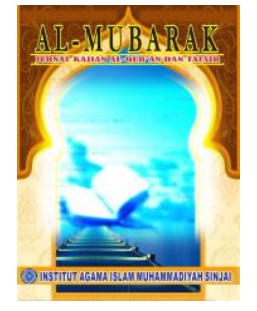

\section{Al-MUBARAK}

Jurnal Kajian Al-Quran \& Tafsir

Volume 5, No. 1, 2020

P-ISSN: 2548-7248

E-ISSN: 2715-5692

Homepage : http://journal.iaimsinjai.ac.id/indeks.php/al-mubarak

imperialism. Selama berabad-abad orang kulit putih mengira bahwa mereka adalah manusia istimewa yang ditakdirkan untuk "membudayakan" bangsabangsa berwarna. Hal ini seperti apa yang telah terjadi di Afrika Selatan di mana keturunan sering dipergunakan untuk melegitimasi hak-hak istimewa dan menyingkirkan orang-orang yang tidak dikehendaki atau disebut dengan rasisme (Abad Badruzaman, 2009: 206-207).

Begitupun dengan kekuasaan dan kekayaan, keduanya sering dipakai untuk menindas orang lain. Sering, lantaran mempunyai wewenang orang bertindak semaunya. Allah swt. telah mengingatkan di dalam Al-Qur`an bagaimana Fir`aun menyeret ribuan budak untuk membangun piramid, kuburan para raja. Fir`aun memberikan hak istimewa kepada suatu kelompok masyarakat untuk menindas kelompok lain. Apalagi dengan kekayaan yang juga sering dijadikan alat untuk memeras orang lain. Banyak orag kaya yang mengira bahwa dengan uangnya yang banyak ia dapat berbuat apapun. Karena jumla pencari kerja yang begitu banyak, terkadang ia tidak segan-segan mengupah mereka dengan upah yang tak akan mencukupi kehidupannya. Tenaga kerja ia peras hanya agar keuntungannya bertambah (Abad Badruzaman, 2009: 207-208).

Jika merujuk pada prinsip tauhid, maka penindasan, kesewenang-wenangan, otoriter, dan eksploitasi itu bisa disebut dengan "thagut". Sebab di dalam alQur'an, Allah swt. berfirman:

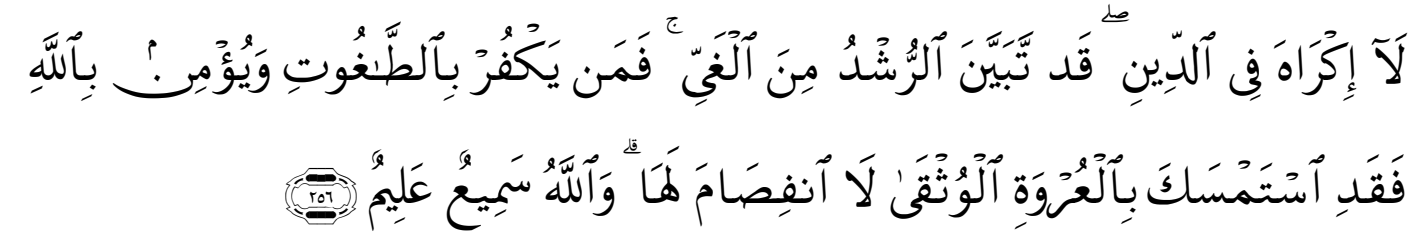

Terjemahnya:

"Tidak ada paksaan dalam (menganut) agama (Islam), sesungguhnya telah jelas (perbedaan) antara jalan yang benar dengan jalan yang sesat. Barang siapa ingkar kepada Thagut dan beriman kepada Allah, maka sungguh, dia telah berpegang (teguh) pada tali yang sangat kuat yang tidak akan putus. Allah Maha Mendengar, Maha Mengetahui." (QS. Al-Baqarah: 256)

Kata “" "طغا - بطغو" yang berarti melewati ketentuan atau melewati batas. Jika dikaitkan dengan manusia berarti ia sombong dan melakukan pelanggaran besar berupa kedzaliman dan kemaksiatan, 


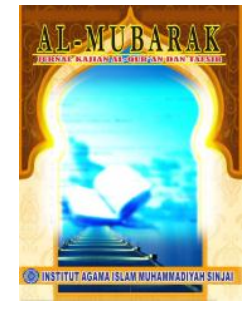

\section{Al-MUBARAK}

Jurnal Kajian Al-Quran \& Tafsir

Volume 5, No. 1, 2020

P-ISSN: 2548-7248

E-ISSN: 2715-5692

Homepage : http://journal.iaimsinjai.ac.id/indeks.php/al-mubarak

atau terbawa ajakan setan, sehingga menyimpang dari kebenaran. Oleh karenanya, manusia yang melakukan pelanggaran disebut "الطاغي" (Tim Penyusun Ensiklopedia al-Qur'an, 2007: 998).

Dari ayat ini dapat dipahami bahwa barang siapa yang mampu dan berhasil melepaskan diri dari belenggu kekuatan-kekuatan tiranik, yang datang dari dalam dirinya sendiri ataupun dari luar, kemudian ia berhasil berpegang pada kebenaran yang sejati, maka sungguh ia telah menempuh hidup yang aman dan sentosa. Oleh karena itu, kesanggupan seseorang untuk melepaskan diri dari penindasan dan kesewenang-wenangan merupakan efek pembebasan sosial semangat tauhid. Bahkan menentang, melawan, menghapus tindakan tersebut adalah konsekuensi logis paham Ketuhanan Yang Maha Esa (Nurchalish Madjid, 2005: 86). Hal ini memang merupakan tugas setiap rasul untuk menentang segala bentuk penindasan sebagaimana disebutkan dalam al-Qur'an:

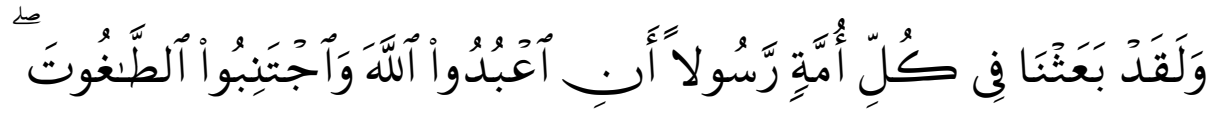

Terjemahnya:

"Dan sungguh, Kami telah mengutus seorang rasul untuk setiap umat (untuk menyerukan), Sembahlah Allah, dan jauhilah Thagut." (QS. Al-Nahl: 36).

Di samping itu pula, Farid Esack menganggap bahwa apartheid dicela dan harus dihapuskan lantaran "menolak secara terang-terangan sifat ketauhidan umat manusia sebagaimana yang dinyatakan oleh Allah swt. dalam al-Qur`an bahwa "manusia adalah bangsa yang satu":

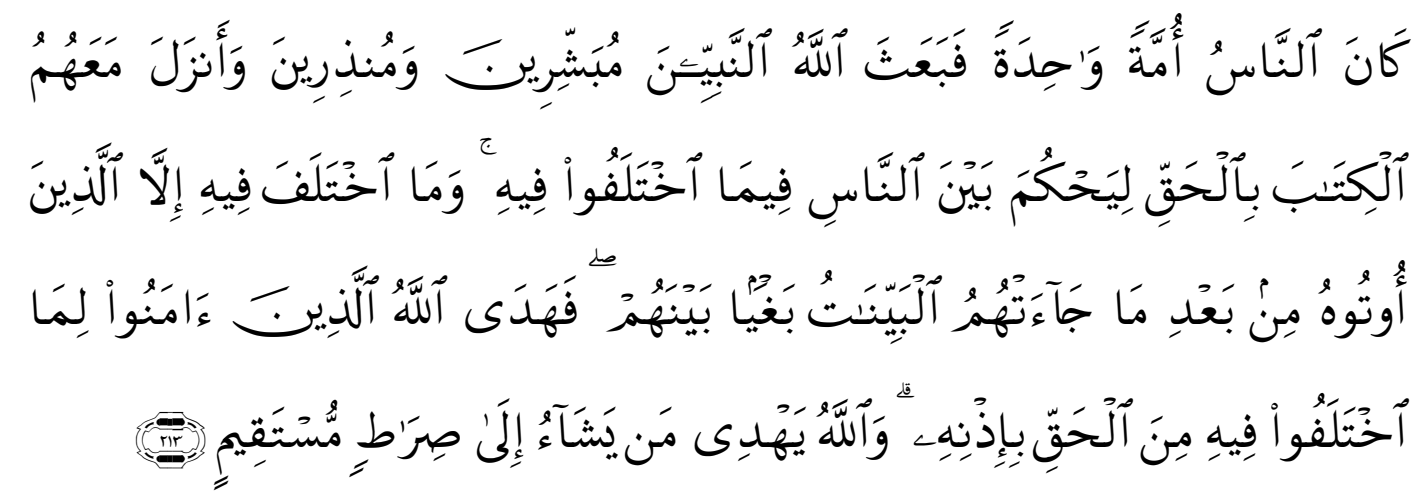

Terjemahnya:

"Manusia itu (dahulunya) satu umat. Lalu Allah mengutus para nabi (untuk) menyampaikan kabar gembira dan peringatan. Dan diturunkan-Nya bersama mereka Kitab yang mengandung kebenaran, untuk memberi keputusan di antara manusia tentang perkara yang mereka perselisihkan. Dan yang 


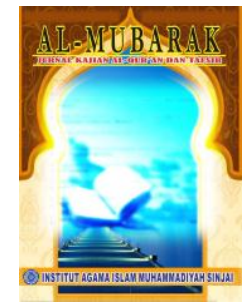

AI-MUBARAK

Jurnal Kajian Al-Quran \& Tafsir

Volume 5, No. 1, 2020

P-ISSN: 2548-7248

E-ISSN: 2715-5692

Homepage : http://journal.iaimsinjai.ac.id/indeks.php/al-mubarak

berselisih hanyalah orang-orang yang telah diberi (Kitab), setelah buktibukti yang nyata sampai kepada mereka, Karena kedengkian di antara mereka sendiri. Maka dengan kehendak-Nya, Allah memberi petunjuk kepada mereka yang beriman tentang kebenaran yang mereka perselisihkan. Allah memberi petunjuk kepada siapa yang Dia kehendaki ke jalan yang lurus." (QS. Al-Baqarah: 213)

Dari ayat inilah Farid Esack kemudian memandang bahwa sistem apartheid merupakan salah satu bentuk syirk karena dari ciri dan praktik sosialnya, sengaja memilah-milah orang secara etnis, ia menolak kesatuan umat manusia yang merupakan refleksi dari tauhid. Dengan demikian, interpretasi tauhid dalm alQur'an memang perlu dijadikan sebagai spirit dan pijakan dalam melakukan aksi pembebasan. Dalam hal ini Farid Esack sepakat dengan pendapat Ebrahim Rasool yang ia kutip bahwa keyakinan tauhid, dengan segala implikasinya, harus berpengaruh mutlak dalam kesadaran manusia, dan sebelum ini tercapai, kita tak

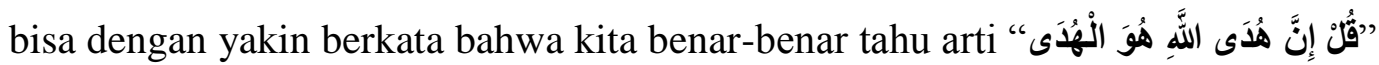
Katakanlah: Sesungguhnya petunjuk Allah adalah petunjuk yang benar" (QS. AlBaqarah: 120). Begitu keyakinan akan ketauhidan Allah beserta implikasinya tertanam dalam kesadaran kita, dan kita menerima petunjuk Allah sebagai petunjuk yang benar, kita pun telah mencapai tujuan Islam (Farid Esack, 1997: 92-93).

Lebih lanjut Farid Esack menjelaskan bahwa Al-Qur`an memandang seluruh dimensi eksistensi sebagai perluasan dari realitas yang saling terkait. Firman Tuhan, yang mencerminkan sifat-sifat-Nya, memuat tingkat holisme dan kelengkapan tertinggi. Ini berarti bahwa filsafat moral Al-Qur`an meliputi seluruh dimensi aktivitas manusia. Bahkan gagasan bahwa Al-Qur`an bicara soal spiritualitas dan politik, atau moralitas dan ekonomi tak cukup merefleksikan kelengkapan ini, karena hal itu menyiratkan bahwa bidang-bidang ini berbeda satu sama lain. Padahal Al-Qur`an memandang semua ini sebagai aspek-aspek perluasan yang terpadu. Jadi, dengan memandang tauhid sebagai prinsip hermeneutika berarti bahwa berbagai pendekatan kepada Al-Qur`an - baik filosofis, spiritual, hukum, maupun politis - mesti dilihat sebagai komponen dari satu jalinan yang saling terkait. Semuanya diperlukan untuk mengungkapkan keutuhan pesan-pesan Tuhan, karena tak ada satu pendekatan secara tunggal bisa 


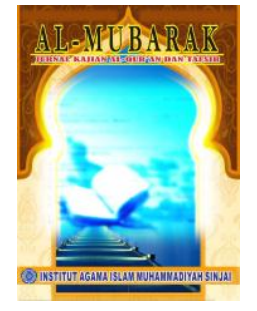

AI-MUBARAK

Jurnal Kajian Al-Quran \& Tafsir

Volume 5, No. 1, 2020

P-ISSN: 2548-7248

E-ISSN: 2715-5692

Homepage : http://journal.iaimsinjai.ac.id/indeks.php/al-mubarak

mewujudkannya sepenuhnya. Dengan kata lain, setiap pendekatan khususnya pendekatan politik, harus mengingat prinsip tauhid, jika tidak Al-Qur`an hanya akan menjadi alat untuk mendukung satu pandangan spesifik yang terpisah dari etos dasarnya (Farid Esack, 1997: 93).

Pendapat Farid Esack ini sejalan dengan pemikiran Muhammad Abduh yang mengatakan bahwa esensi ajaran Islam dapat disimbolkan dengan tauhid, suatu istilah yang sebenarnya tak terdapat dalam al-Qur'an. Dari persepsi ini, menurut Muhammad Abduh, dapat ditarik kesimpulan bahwa Islam itu teosentris, alias agama yang berpusat pada Tuhan. Dengan menjadikan konsep tauhid sebagai teman sentral, ada beberapa gagasan yang bisa dikembangkan dari konsep itu; yakni pembebasan manusia dari segala bentuk penghambaan (harta ataupun kekuasaan), persamaan di antara manusia, rasionalitas, kebebasan berpikir, dan persatuan umat. Dengan demikian, Islam, kata Abduh, bertujuan membebaskan manusia dari segala bentuk penghambaan atau diistilahkan dengan "objek pengabdian". Karena secara historis manusia tidak bisa melepaskan diri dari objek pengabdian, maka yang perlu dicari ialah konsep kepada siapa manusia itu harus mengabdi, yang tidak menyebabkan kemiskinan pribadi, yang secara kemanusiaan dapat dipertanggungjawabkan (Dawam Rahardjo, 2005: 208-211).

Muhammad Abduh menjelaskan lebih lanjut bahwa menurut al-Qur'an, satu-satunya cara untuk memperoleh kebebasan sejati ialah dengan menundukkan diri kepada Allah, yaitu Tuhan yang digambarkan dalam QS. al-Baqarah/2: 63:

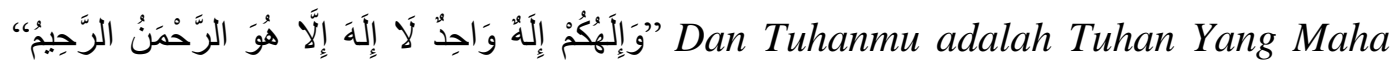
Esa; tidak ada Tuhan melainkan Dia Yang Maha Pemurah lagi Maha Penyayang". Konsep agama yang seperti ini bukannya tidak mengandung dimensi kemanusiaan. Dalam Al-Qur`an dijelaskan bahwa dimensi vertikal (hubungan makhluk dengan Pencipta) berkaitan dengan dimensi horizontal (hubungan makhluk dengan sesama makhluk). Bahkan, Al-Qur`an mengatakan bahwa bila orang yang tak memiliki kedua dimensi tersebut sekaligus, maka yang diterimanya adalah malapetaka (Dawam Rahardjo, 2005: 211-212), seperti yang terdapat dalam Q.S. Āli Imrān: 112: 


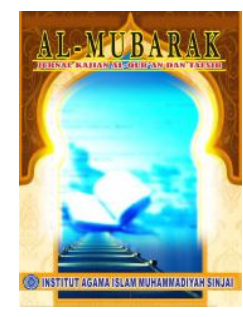

\section{Al-MUBARAK}

Jurnal Kajian Al-Quran \& Tafsir

Volume 5, No. 1, 2020

P-ISSN: 2548-7248

E-ISSN: 2715-5692

Homepage : http://journal.iaimsinjai.ac.id/indeks.php/al-mubarak

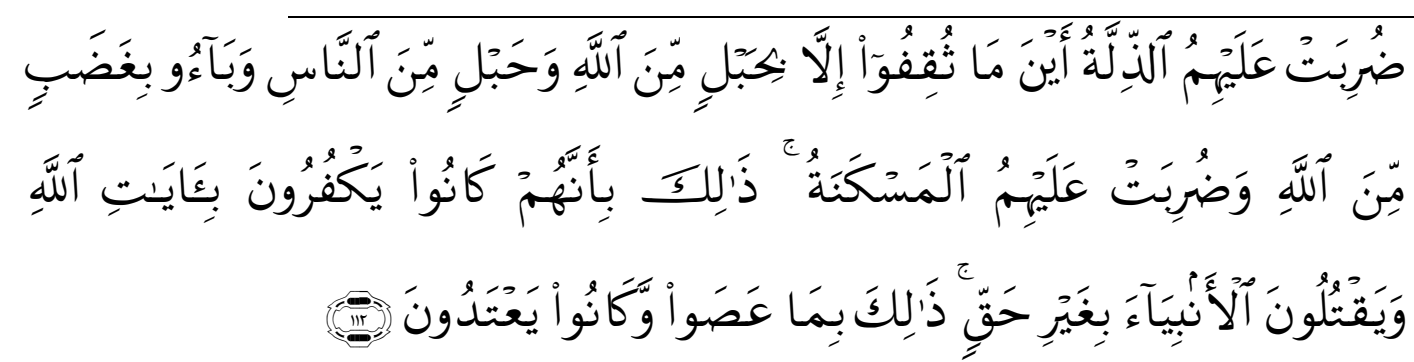

Terjemahnya:

"Mereka diliputi kehinaan di mana saja mereka berada, kecuali jika mereka berpegang kepada tali (agama) Allah dan tali (perjanjian) dengan manusial, dan mereka kembali mendapat kemurkaan dari Allah dan mereka diliputi kerendahan. Yang demikian itu karena mereka kafir kepada ayat-ayat Allah dan membunuh para nabi tanpa alasan yang benar. Yang demikian itu disebabkan mereka durhaka dan melampaui batas." Inilah yang dimaksud oleh Al-Qur'an sebagai konsep beragama yang baik dan benar. "Dan siapakah yang lebih baik agamanya dari pada orang yang ikhlas menyerahkan dirinya kepada Allah, sedang diapun mengerjakan kebaikan" (Q.S. Al-Nisa: 125).

Oleh karenanya, Farid Esack menyimpulkan bahwa pandangan yang sempit tentang ibadah formal akan memupuskan kehidupan spiritual suatu kaum. Seyogianya, penekanan pada perjuangan kaum tertindas diperlukan untuk menghidupkan kembali ibadahnya. Dengan demikian, dalam mengkonstruksi hermeneutika pembebasan Al-Qur`an, tauhid menuntut penolakan wacana yang dilandasi syirk, yaitu adanya dualisme yang memisahkan teologi dari analisis sosial. Menemukan unsur teologis dalam situasi historis dan sosiopolitik tertentu berarti memahami yang disebut belakangan itu. Pemahaman ini tidak muncul dari pengabaian hal-hal duniawi, tidak juga membantu dalam menemukan unsur teologis dalam seluruh usaha manusia. Ideal Islam adalah entitas terpadu yang berpegang pada satu Tuhan dan pada kesatuan (Farid Esack, 1997: 94).

\subsection{Interpretasi Tauhid sebagai Landasan Teologi Pembebasan}

Sebagai wahyu yang di-kalam-kan langs ung oleh Tuhan, Al-Qur`an hadir tentunya bukan hanya sebagai bundelan kertas tanpa pesan yang menyertainya. Sungguhpun demikian, bagi sebagian kalangan, nampaknya Al-Qur`an lebih menarik untuk ditelurusi hanya pada sebatas teksnya saja, sedangkan untuk menguak dan mengungkap pesan praktis yang dikandung oleh Al-Qur`an itu sendiri belumlah memadai. Hal ini hanya menjadikan Teks (Nash) yang sakral itu 


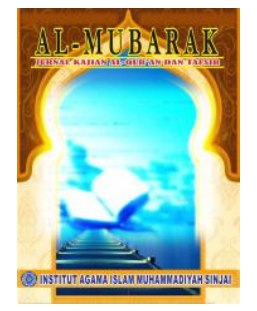

AI-MUBARAK

Jurnal Kajian Al-Quran \& Tafsir

Volume 5, No. 1, 2020

P-ISSN: 2548-7248

E-ISSN: 2715-5692

Homepage : http://journal.iaimsinjai.ac.id/indeks.php/al-mubarak

tertabiri dalam keunikan dan kesakralannya sendiri walau harus mengorbankan kekayaan pesan yang dikundungnya. Oleh karenanya, maka tidak heran jika Adonis, seorang pemikir dan sastrawan asal Syiria menyatakan bahwa Al-Qur`an sebenarnya tidak "dibaca" oleh masyarakat luas, Ia hanya diposisikan tidak lebih hanya sebagai teks naratif yang diyakini atau irama yang didendangkan (Ahmad Fawaidz, 2004: 2).

Padahal jika dilihat dari proses pewahyuannya, Al-Qur`an tidak diturunkan secara sekaligus, melainkan bertahap sedikit demi sedikit dalam waktu 23 tahun untuk menjawab problem-problem riil kemanusiaan. Di bawah kontrol Nabi Muhammad, Al-Qur`an telah menjadi poros dalam kehidupan umat manusia. Beliau sendiri yang bertindak sebagai penafsir untuk menjelaskan makna dan kandungan dari Al-Qur`an melalui hadis dan sunnahnya. Sebagai teks wahyu, AlQur`an telah terhenti seiring dengan wafatnya Nabi Muhammad saw. Kontak umat Islam dengan Nabi Muhammad sebagai penyampai Al-Qur`an akan terputus oleh rentang waktu yang panjang. Kini Al-Qur`an hanya sendirian di dalam mengunjungi para pembacanya tanpa ada kontrol dari Muhammad saw. Al-Qur`an akan sampai ke pelosok-pelosok dunia dan terus mengikuti sejarah dan peradaban manusia tanpa didampingi oleh Nabi sebagai pembawa dan penerima pesan dari Allah swt. (Abd. Moqsith Ghazali, 2004: 38-39).

Oleh karenanya, seorang penafsir harus berperan penting dalam mnjembatani antara dunia teks al-Qur'an dengan realitas yang ada, atau dengan kata lain "Isthanthiq al-Qur'an" (buatlah al-Qur'an berbicara). Al-Qur'an tidak diturunkan pada masyarakat yang hampa budaya, tetapi diturunkan pada masyarakat lokal Arab yang telah memiliki budaya dengan karakteristik tertentu. Al-Qur'an diturunkan sebagai rahmatan lil 'alamin untuk merespons konteks global kemanusiaan dan kealaman. Maka dengan demikian, penafsir memerlukan kajian kritis-komprehensif agar al-Qur'an yang berasal dari masa lalu dapat didialogkan dengan konteks kekinian dengan tingkat dialog yang objektif, komunikatif, transformatif, kondusif, proporsional, produktif, dan dinamis (Yayan Rahtikawati dan Dadan Rusmana, 2013: 83 dan 457). 


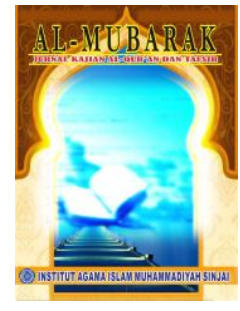

\section{Al-MUBARAK}

Jurnal Kajian Al-Quran \& Tafsir

Volume 5, No. 1, 2020

P-ISSN: 2548-7248

E-ISSN: 2715-5692

Homepage : http://journal.iaimsinjai.ac.id/indeks.php/al-mubarak

Untuk mewujudkan hal tersebut, beberapa mufassir kontemporer seperti

Hassan Hanafi dan termasuk juga Farid Esack megusulkan apa yang disebut dengan hermeneutika pembebasan. Hermeneutika bukan hanya sebuah seni interpretasi dan teori pemahaman, namun juga ilmu yang menjelaskan bagaimana wahyu diresepsi dari tingkat kata ke tingkat realitas, dan dari logos ke praksis (Moch. Nur Ichwan, 2003: 39). Oleh karenanya, pada dekade 1980-an, Hassan Hanafi menyusun sebuah karya monumental yang berjudul ad-Din wa AtsTsaurah yang berisi hermeneutika praksis sosial dan menyebut metode penafsirannya dengan "metode sosial” (al-Manāhij al-Ijtimăì). Ia menyusun sebuah tafsir yang spesifik (at-tafsir al-juzî), berdasarkan tema-tema tertentu (altafsìr al-maudhūi) sesuai dengan zaman (al-tafsir al-zamāni), sehingga bersifat tentatif. Suatu penafsiran yang menyentuh realitas umat (al-tafsīr al-wāqiīi) dan berorientasi pada makna dan tujuan, serta sesuai dengan pengalaman hidup tempat penafsir hidup (Yayan Rahtikawati dan Dadan Rusmana, 2013: 469-470).

Begitupun dengan Farid Esack yang telah memberikan eksemplar yang baik perihal kerja tafsir pembebasan ini. Sejak semula beliau merefleksikan kondisi-kondisi obyektif masyarakat Afrika Selatan, baru kemudian melihat hamparan teks Al-Qur`an, hingga ditemukan makna-maknanya yang baru dari teks tersebut. Di sini ketertindasan dan ketidakadilan yang menimpa rakyat Afrika Selatan, termasuk dirinya, menjadi fokus perhatian utama Farid Esack dalam melakukan aksi pembebasan. Dengan asumsi teologisnya ia berkata bahwa (1997, 10):

"I believe that the Transcendent, God, has intervened and is intervening in history. This intervention, however, can make no sense other than within the framework of humankind's existence here on earth. The religious legacy of South African Muslims, and our engoing commitment to that legacy, compel us to find new ways of describing the way God may address a world in which human beings constantly change."

Inilah signifikansi dari hasil interpretasi Farid Esack terhadap ayat-ayat alQur'an, khususnya mengenai ayat-ayat tauhid, di mana beliau berusaha membentuk sebuah tafsir revolusioner yang dapat menjadi landasan normatif atau mungkin ideologi bagi perjuangan umat dalam menghadapi segala bentuk ketidakadilan dan kesewenang-wenangan, baik yang dilancarkan oleh kekuatan- 


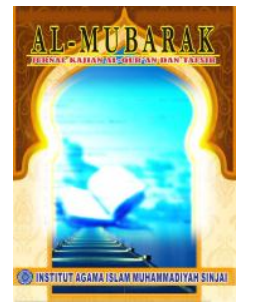

AI-MUBARAK

Jurnal Kajian Al-Quran \& Tafsir

Volume 5, No. 1, 2020

P-ISSN: 2548-7248

E-ISSN: 2715-5692

Homepage : http://journal.iaimsinjai.ac.id/indeks.php/al-mubarak

kekuatan dari luar tubuh umat, maupun oleh unsur otoritarian yang terdapat dalam masyarakat Muslim itu sendiri.

Karena sesungguhnya Farid Esack tidak sepaham dengan teologi yang hanya berfokus pada ritual keagamaan dan menonjolkan kesalehan pribadi saja, sembari mengabaikan atau menyangkal bahwa strutur sosioekonomi berperan dalam membentuk nilai-nilai pribadi. Baginya, orang-orang yang mementingkan agama itu bersifat konservatif, ingin mempertahankan status quo, dan tak bersimpati pada penderitaan rakyat kulit hitam dan kaum miskin. Mereka memperlihatkan bahwa potret orang beragama itu adalah orang yang eksis dengan kesalamatan dan kesalehan pribadi, berorientasi pada akhirat, dan tidak peduli atau membenarkan secara diam-diam atas sistem sosial yang melakukan penindasan dan ketidak adilan sosial (Farid Esack, 1997: 7-8).

Sedangkan teologi pembebasan adalah usaha praksis bagi keadilan yang komprehensif, refleksi teologis yang muncul dari konteks, dan membentuk ulang praksis berdasarkan pada refleksi itu. Di Afrika Selatan, telogi pembebasan ini terwujud dalam diri sejumlah tokoh agama dan organisasi keagamaan yang merasa berdosa karena hanya berdiam diri di hadapan penindasan, mengiyakan eksploitasi, dan mengamini kekuasaan yang menindas orang-orang tak berdaya. Para penganut teologi ini mencari Tuhan "yang aktif" di dalam reaitas, yang menghendaki kemerdekaan bagi semua orang, serta perubahan yang simultan pada jiwa dan struktur sosial. Sosok Tuhan yang keesaan-Nya terpantul pada kesatuan umat-Nya (Farid Esack, 1997: 8). Dengan cara seperti ini, termasuk apa yang telah dilakukan oleh para penafsir pembebasan lainnya, sangat terasa bahwa Al-Qur`an bukan hanya sekedar tumpukan kertas belaka, melainkan teks yang benar-benar di(hidup)kan dalam masyarakat. Oleh karenanya, adanya tafsir atau hermeneutika pembebasan ini merupakan solusi untuk mengatasi berbagai kebuntuan metodologis seperti yang tampak di dalam produk-produk tafsir sebelumnya (Abd. Moqsith Ghazali, 2004: 55).

Oleh karenanya, gagasan teologi yang berkembang di Afrika Selatan juga dikenal dengan sebutan teologi pembebasan Al-Qur`an (Qur`anic theology of liberation). Bagi Farid Esack sendiri, teologi ini adalah sesuatu yang bekerja ke 


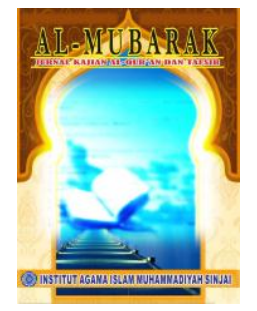

AI-MUBARAK

Jurnal Kajian Al-Quran \& Tafsir

Volume 5, No. 1, 2020

P-ISSN: 2548-7248

E-ISSN: 2715-5692

Homepage : http://journal.iaimsinjai.ac.id/indeks.php/al-mubarak

arah pembebasan agama dari struktur serta ide sosial, politik, dan religius yang didasarkan pada pembebasan seluruh masyarakat dari semua bentuk ketidakadilan dan eksploitasi ekonomi, ras, gender, kelas, dan agama yang mendapatkan ilhamnya dari Al-Qur`an dan perjuangan para nabi. Hal ini diwujudkan dengan melibatkan Al-Qur`an dan teladan nabi dalam proses refleksi teologis bersama dan berkelanjutan demi praksis liberatif yang semakin meningkat (Farid Esack, 1997: 83).

\section{Kesimpulan}

Dengan adanya problem kemanusiaan yang dihadapi rakyat Afrika Selatan, Farid Esack menganggap bahwa apartheid dicela dan harus dihapuskan lantaran "menolak secara terang-terangan sifat ketauhidan umat manusia sebagaimana yang dinyatakan oleh Allah swt. dalam al-Qur'an bahwa "manusia adalah bangsa yang satu". Ia memandang bahwa sistem apartheid merupakan salah satu bentuk syirk karena dari ciri dan praktik sosialnya, sengaja memilah-milah orang secara etnis, ia menolak kesatuan umat manusia yang merupakan refleksi dari tauhid. Dari hasil interpretasi Farid Esack terhadap ayat-ayat al-Qur'an, khususnya mengenai ayat-ayat tauhid, beliau berusaha membentuk sebuah tafsir revolusioner yang dapat menjadi landasan normatif atau mungkin ideologi bagi perjuangan umat dalam menghadapi segala bentuk ketidakadilan dan kesewenang-wenangan, baik yang dilancarkan oleh kekuatan-kekuatan dari luar tubuh umat, maupun oleh unsur otoritarian yang terdapat dalam masyarakat Muslim itu sendiri.

\section{Daftar Pustaka}

Badruzaman, Abad. (2009). Dari Teologi Menuju Aksi; Membela yang Lemah, Menggempur Kesenjangan. Yogyakarta: Pustaka Pelajar.

Budiman, Agus. (2013). "Politik Apartheid di Afrika Selatan" dalam Jurnal Artefak Vol 1. No. 1. Edisi Januari 2013.

Dipoyudo, Kirdi. (1977). Afrika dalam Pergolakan. Jakarta: Centre for Strategic and International Studies.

El Rais, Heppy. (2012). Kamus Ilmiah Populer. Yogyakarta: Pustaka Pelajar. 


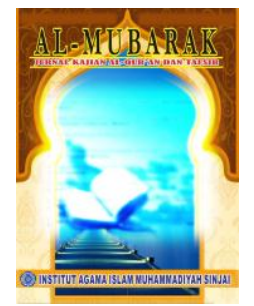

\section{Al-MUBARAK}

Jurmall Kajian All-Quran \& Tafsir

Volume 5, No. 1, 2020

P-ISSN: 2548-7248

E-ISSN: 2715-5692

Homepage : http://journal.iaimsinjai.ac.id/indeks.php/al-mubarak

Esack, Farid. (1996). "Spektrum Teologi Progresif di Afrika Selatan" dalam Dekonstruksi Syari`ah (II): Kritik Konsep, Penjelajahan Lain, terj. Farid Wajidi. Yogyakarta: LKiS.

------. (1997). Qur`an, Liberation and Pluralism: An Islamic Perspective of Interreligious Solidarity against Oppression. Inggris: Oneworld Publications.

Ghazali, Abd Moqsith. (2004). "Menuju Tafsir Al-Qur`an yang Membebaskan" dalam Jurnal Tashwirul Afkar. Edisi No. 18 Tahun 2004.

Ichwan, Moch. Nur (2003). Meretas Kesarjanaan Kritis Al-Qur'an; Teori Hermeneutika Nasr Abu Zayd. Jakarta: Teraju.

Madjid, Nurcholish. (2005). Islam Doktrin dan Peradaban. Jakarta: Paramadina.

Rahardjo, M. Dawam. (2005). Paradigma Al-Quran; Metodologi Tafsir dan Kritik Sosial. Jakrta: PSAP Muhammadiyah

Rahtikawati, Yayan \& Dadan Rusmana. Metodologi Tafsir Al-Quran: Strukturalisme, Semantik, Semiotik, dan Hermeneutik. Bandung: Pustaka Setia.

Shihab, M. Quraish. (2002). Tafsir Al-Mishbah. Jakarta: Lentera Hati.

Sjadzili, Ahmad Fawaidz (2004). "Al-Qur’an dan 'Juru Bicara` Tuhan” dalam Jurnal Tashwirul Afkar. Edisi No. 18 Tahun 2004.

Su'ud, M., \& Syukron Affani. (2009). Islam dan Transformasi Budaya: Mewujudkan Perubahan Menuju Masyarakat Progresif. Yogyakarta: Logung Pustaka.

Tim Penyusun Ensiklopedia al-Qur'an. (2007). Ensiklopedia Al-Qur'an: Kajian Kosakata. Jakarta: Lentera Hati.

Zakariya, Ahmad bin Faris. (1979). Maqayis Al-Lugah. ttp: Dar al-Fikr. 